\title{
Anaemia in Bangladesh: a review of prevalence and aetiology
}

\author{
Faruk Ahmed* \\ Institute of Nutrition and Food Science, University of Dhaka, Dhaka-1000, Bangladesh
}

Submitted 23 August 1999: Accepted 20 March 2000

\begin{abstract}
Objective: This paper provides a comprehensive review of the changes in the prevalence and the extent of anaemia among different population groups in Bangladesh up to the present time. The report also focuses on various factors in the aetiology of anaemia in the country.

Design and setting: All the available data have been examined in detail, including data from national nutrition surveys, as well as small studies in different population groups.

Results: Over the past three decades a number of studies including four national nutrition surveys (1962/64; 1975/76; 1981/82 and 1995/96) have been carried out to investigate the prevalence of anaemia among different population groups in Bangladesh, and have demonstrated a significant public health problem. Since the $1975 / 76$ survey the average national prevalence of anaemia has not fallen; in 1995/96, $74 \%$ were anaemic (64\% in urban areas and $77 \%$ in rural areas). However, age-specific comparisons suggest that the rates have fallen in most groups except adult men: in preschool children in rural areas it has decreased by about $30 \%$, but the current level (53\%) still falls within internationally agreed high risk levels. Among the rural population, the prevalence of anaemia is $43 \%$ in adolescent girls, $45 \%$ in nonpregnant women and $49 \%$ in pregnant women. The rates in the urban population are slightly lower compared with rural areas, but are high enough to pose a considerable problem. It appears that severe anaemia in the Bangladeshi population is less frequent, possibly present among only $2-3 \%$ of the population. The data on the aetiology of anaemia reveal that iron deficiency may be a substantial cause of anaemia in the Bangladeshi population. Other dietary factors in addition to parasitic infestations may also precipitate the high prevalence of anaemia.

Conclusions: While the overall prevalence of anaemia among the Bangladeshi population is still very high, the rates of severe anaemia are almost non-existent. A large proportion of anaemia can be attributed to iron deficiency. There is a need for a comprehensive strategy for the prevention and control of anaemia in Bangladesh.
\end{abstract}

Anaemia is a condition characterized by a reduction in red cell mass and a decrease in the concentration of haemoglobin in the blood. Anaemia is actually a statistical construct: it is defined as existing in an individual whose haemoglobin concentration has fallen below a threshold lying at two standard deviations below the median for a healthy population of the same age, sex and stage of pregnancy. The World Health Organization (WHO) has recommended cut-off points of haemoglobin levels for various population groups for determining the presence of nutritional anaemia, as shown in Table $1^{1}$. Additionally, epidemiological criteria for assessing the severity and magnitude of nutritional anaemia in populations have been proposed (Table 2$)^{2}$.

The causes of anaemia in a population are multiple. However, in public health terms, iron deficiency is by far the most important cause of nutritional anaemia worldwide. Iron deficiency anaemia may result from one, or a combination of four, major factors: (i) inadequate dietary intake of iron and/or low dietary bioavailability ${ }^{3}$; (ii) increased iron needs at various stages of life, such as during pregnancy and the periods of rapid growth in small children and during adolescence ${ }^{4}$; (iii) chronic iron losses such as during menstruation of women of reproductive age, or due to ulcers and parasitic infestations ${ }^{3,5}$; and (iv) impaired iron utilization after it is absorbed as occurs in chronic and repeated infections and in vitamin A deficiency ${ }^{6,7}$. Causes of nutritional anaemia other than iron deficiency include deficiencies of folic acid, vitamin $\mathrm{C}$, copper, and vitamins $\mathrm{B}_{2}$ and $\mathrm{B}_{12}$. Genetically determined haemoglobinopathies such as thalassaemia are other causes of anaemia in some people ${ }^{8}$.

The consequences of anaemia have serious health implications. Iron deficiency and iron deficiency anaemia 
Table 1 Haemoglobin cut-off points used to define anaemia in populations living at sea level ${ }^{1}$

\begin{tabular}{lc}
\hline Group/age/physiological status & $\begin{array}{c}\text { Haemoglobin cut-off } \\
\left(\mathrm{g} \mathrm{l}^{-1}\right)\end{array}$ \\
\hline Children & \\
$0.5-5$ years & $<110.0$ \\
$5-11$ years & $<115.0$ \\
$12-13$ years & $<120.0$ \\
Men & $<130.0$ \\
Women & \\
$\quad$ Non-pregnant & $<120.0$ \\
Pregnant & $<110.0$ \\
\hline
\end{tabular}

Table 2 A classification of the severity of anaemia in pregnant women in relation to public health significance ${ }^{2}$

\begin{tabular}{|c|c|c|}
\hline $\begin{array}{l}\text { Category of public health } \\
\text { significance }\end{array}$ & $\begin{array}{l}\text { Mild-moderate } \\
\text { anaemia } \\
\left(\mathrm{Hb} 70-109 \mathrm{gl}^{-1}\right)\end{array}$ & $\begin{array}{l}\text { Severe anaemia } \\
\left(\mathrm{Hb}<70 \mathrm{gl}^{-1}\right)\end{array}$ \\
\hline High & $>40.0 \%$ & $>10.0 \%$ \\
\hline Medium & $10.0-39.9 \%$ & $1.0-9.9 \%$ \\
\hline Low & $1.0-9.9 \%$ & $0.1-0.9 \%$ \\
\hline
\end{tabular}

carry clear risks in the short term to the pregnant woman and her offspring, with increased risk of complications in pregnancy and the perinatal period, poorer foetal growth and chances of survival ${ }^{9,10}$. In Bangladesh, about $26 \%$ of maternal deaths are caused by nutritional anaemia and postpartum haemorrhage ${ }^{11}$. Most recent evidence relates iron status during pregnancy with poor fetal growth and increased risks later in life from chronic diseases such as heart disease, hypertension and maturity onset diabetes ${ }^{12}$. The more insidious social cost of iron deficiency is impaired work performance ${ }^{13}$ and a limitation in intellectual development ${ }^{14}$, which together open the way to constrained social and economic development. A recent report on the economic consequences of iron deficiency anaemia indicated that, for Bangladesh, the annual per capita productivity loss due to iron deficiency is US\$4.19 or $1.9 \%$ of the gross domestic product ${ }^{15}$.

Anaemia is recognized as a major public health problem, affecting over 1.2 billion people in both the developed and developing countries ${ }^{9}$. Compilations of the prevalence of anaemia worldwide show a large variation among regions, and although the prevalence is highest in developing countries, it is also common in industrialized countries $^{16}$. In Bangladesh, anaemia is considered to be one of the major public health problems. The objective of this paper is to summarize available information about both the prevalence and trends in anaemia in Bangladesh, and thus review the present situation of anaemia in the country. There is a focus on various factors in the aetiology of anaemia. The data presented here are not all based on representative national sampling. Rather, the review has drawn upon published papers, reports and documents on studies made over the past three decades.

\section{Situation assessment and analysis}

Until now there has not been a national survey of anaemia in Bangladesh. However, there have been four national nutrition surveys carried out in the country, which mainly covered the rural population and investigated the prevalence of anaemia as a part of the survey. The first national nutrition survey of Bangladesh in 1962/64 (when the country was known as East Pakistan) revealed that over a third of the total population had anaemia ${ }^{17}$. The second and third nutrition surveys in 1975/76 and 1981/82, respectively, reported a prevalence of $70 \%$ for anaemia among the rural population ${ }^{18,19}$. The most recent survey in $1995 / 96$ revealed that the overall prevalence of anaemia was $74 \%$, being $63.7 \%$ for the urban and $77.1 \%$ for the rural population $^{20}$

Besides national nutrition surveys, there have been a number of studies which have been carried out to investigate the prevalence of anaemia in different population groups. Not all studies have been of groups or populations that are representative of the population of Bangladesh; however, the information is of considerable value in indicating the magnitude of the problem. Where possible the extent of the problem has been categorized in relation to population groups by age, sex and physiological state.

\section{Infants and preschool children}

Available data on the prevalence of anaemia in infants and preschool children are summarized in Table 3 . The survey of $1975 / 76$ indicated a prevalence of $82 \%$ for anaemia in children aged $0-4$ years in rural areas ${ }^{18}$, manifesting haemoglobin levels below $110 \mathrm{~g} \mathrm{l}^{-1}$, that decreased to $73 \%$ in $1981 / 82^{19}$ and $69.5 \%$ in $1995 / 96^{20}$. During the $1997 / 98$ vitamin A survey of rural Bangladesh, haemoglobin concentrations of preschool children were measured and indicated a prevalence of $52.7 \%$ for anaemia, while the rate of severe anaemia was only $1.7 \%{ }^{21}$. Besides the national nutrition surveys, a number of studies with small samples have also reported a similarly high prevalence (64-81\%) of anaemia in preschool children in the rural population ${ }^{22,23}$; while the rates were somewhat lower (49$61 \%$ ) in urban populations of the same age group ${ }^{24,25}$.

In summary, the prevalence of anaemia in preschool children has decreased over the last three decades. However, the current prevalence falls within the high risk category according to the epidemiological criteria set by the $\mathrm{FAO} / \mathrm{WHO}^{2}$ and thus still remains a significant public health problem.

\section{School-age children and adolescents}

A summary of the major findings on the prevalence of anaemia in school-age and adolescent children is shown in Table 4 . The survey of 1962/64 revealed that the levels of anaemia among children aged 5-14 years in rural areas were $46 \%$ and $50 \%$ for males and females, respectively ${ }^{17}$. 
Table 3 Summary of the prevalence data on anaemia among preschool children in Bangladesh

\begin{tabular}{|c|c|c|c|c|c|c|c|c|c|}
\hline Reference & Area & Place & Setting & $\begin{array}{l}\text { Study } \\
\text { period }\end{array}$ & Age group & $\begin{array}{l}\text { Sample } \\
\text { size }\end{array}$ & $\begin{array}{l}\text { Sampling } \\
\text { design }\end{array}$ & Haemoglobin method & $\begin{array}{c}\text { Prevalence } \\
\text { of anaemia } \\
(\%)^{\star}\end{array}$ \\
\hline $\begin{array}{l}\text { INFS } \\
(1977)^{18}\end{array}$ & Rural & 12 sites & Community & $1975-76$ & $0-4$ years & 163 & $\begin{array}{l}\text { Two-stage } \\
\text { systematic } \\
\text { random }\end{array}$ & Cyanomethaemoglobin & 82.0 \\
\hline $\begin{array}{l}\text { INFS } \\
(1983)^{19}\end{array}$ & Rural & 12 sites & Community & $1981-82$ & $0-4$ years & 421 & $\begin{array}{l}\text { Two-stage } \\
\text { systematic } \\
\text { random }\end{array}$ & Cyanomethaemoglobin & 73.0 \\
\hline $\begin{array}{c}\text { Jahan \& } \\
\text { Hossain } \\
(1998)^{20}\end{array}$ & $\begin{array}{l}\text { Rural and } \\
\text { urban }\end{array}$ & $\begin{array}{r}32 \text { sites }(R) \\
9 \text { sites }(U)\end{array}$ & Community & 1995-96 & $0-4$ years & $\begin{array}{l}616(\mathrm{R}) \\
169(\mathrm{U})\end{array}$ & $\begin{array}{l}\text { Systematic } \\
\text { random }\end{array}$ & Cyanomethaemoglobin & $\begin{array}{l}69.5(\mathrm{R}) \\
38.5(\mathrm{U})\end{array}$ \\
\hline $\begin{array}{l}\text { HKI/IPHN } \\
(1999)^{21}\end{array}$ & Rural & 10 sites & Community & 1997-98 & $6-59$ months & 1199 & $\begin{array}{l}\text { Random } \\
\text { sub-sample }\end{array}$ & HemoCue & 52.7 \\
\hline $\begin{array}{l}\text { Saha \& } \\
\text { Ahmad } \\
(1991)^{22}\end{array}$ & Rural & 2 subdistricts & Community & 1978 & $6-48$ months & $\begin{array}{l}89 \dagger \\
68 \ddagger\end{array}$ & $\begin{array}{l}\text { Selected } \\
\text { sample }\end{array}$ & Cyanomethaemoglobin & $\begin{array}{l}77.0 \dagger \\
81.0 \ddagger\end{array}$ \\
\hline $\begin{array}{l}\text { Sultana } \\
(1995)^{24}\end{array}$ & Urban & Dhaka city & Community & 1993 & $6-59$ months & 152 & $\begin{array}{l}\text { Selected } \\
\text { sample }\end{array}$ & Cyanomethaemoglobin & 49.0 \\
\hline $\begin{array}{l}\text { Nahar et al. } \\
(1995)^{25}\end{array}$ & Urban & Dhaka city & Clinic & - & $6-59$ months & 189 & $\begin{array}{l}\text { Selected } \\
\text { sample }\end{array}$ & Cyanomethaemoglobin & 61.4 \\
\hline
\end{tabular}

$\mathrm{R}$, rural; U, urban.

*Defined by a haemoglobin level of $\left\langle 110 \mathrm{gl}^{-1}\right.$.

$\dagger$ In an area with a safe water supply.

$\ddagger$ In an area with no safe water supply.

In the surveys of $1975 / 76$ and $1981 / 82$, overall prevalence was nearly $75 \%{ }^{18,19}$. In the $1995 / 96$ survey it was $78 \%$, being $80.4 \%$ in rural areas and $70.5 \%$ in urban areas ${ }^{20}$. Further, the prevalence was higher in girls (81\%) than in boys $(75 \%)^{20}$. During the $1997 / 98$ national vitamin A survey, the prevalence of anaemia was found to be $38.4 \%$ in rural children aged 6-11 years and 43\% among adolescent girls ${ }^{21}$. However, the rates of severe anaemia (haemoglobin level below $90 \mathrm{gl}^{-1}$ ) among school-age children and adolescent girls were only $2.1 \%$ and $1.0 \%$, respectively ${ }^{21}$. In 1996 in a study of 400 children aged 7-10 years in rural schools in the Savar subdistrict, $51.5 \%$ were

Table 4 Summary of the prevalence data on anaemia among school-age and adolescent children in Bangladesh

\begin{tabular}{|c|c|c|c|c|c|c|c|c|c|}
\hline Reference & Area & Place & Setting & $\begin{array}{l}\text { Study } \\
\text { period }\end{array}$ & $\begin{array}{l}\text { Age group } \\
\text { (years) }\end{array}$ & $\begin{array}{l}\text { Sample } \\
\text { size }\end{array}$ & $\begin{array}{l}\text { Sampling } \\
\text { design }\end{array}$ & Haemoglobin method & $\begin{array}{c}\text { Prevalence } \\
\text { of anaemia } \\
(\%)^{\star}\end{array}$ \\
\hline $\begin{array}{l}\text { US-DHEW } \\
(1966)^{17}\end{array}$ & $\begin{array}{l}\text { Urban and } \\
\text { rural }\end{array}$ & 54 sites & Community & $1962-64$ & $5-14$ & $\begin{array}{l}88 † \\
48 \ddagger\end{array}$ & $\begin{array}{l}\text { Multistage } \\
\text { random }\end{array}$ & Cyanomethaemoglobin & $\begin{array}{l}46.0 † \\
50.0 \ddagger\end{array}$ \\
\hline $\begin{array}{l}\text { INFS } \\
(1977)^{18}\end{array}$ & Rural & 12 sites & Community & $1975-76$ & $5-14$ & $\begin{array}{l}463 † \\
384 \ddagger\end{array}$ & $\begin{array}{l}\text { Two-stage } \\
\text { systematic } \\
\text { random }\end{array}$ & Cyanomethaemoglobin & $\begin{array}{l}74.0 \dagger \\
75.0 \ddagger\end{array}$ \\
\hline $\begin{array}{l}\text { INFS } \\
(1983)^{19}\end{array}$ & Rural & 12 sites & Community & $1981-82$ & $5-14$ & $\begin{array}{l}435 † \\
383 \ddagger\end{array}$ & $\begin{array}{l}\text { Two-stage } \\
\text { systematic } \\
\text { random }\end{array}$ & Cyanomethaemoglobin & $\begin{array}{l}74.0 † \\
73.0 \ddagger\end{array}$ \\
\hline $\begin{array}{l}\text { Jahan \& } \\
\text { Hossain } \\
(1998)^{20}\end{array}$ & $\begin{array}{l}\text { Rural and } \\
\text { urban }\end{array}$ & $\begin{array}{r}32 \text { sites }(\mathrm{R}) \\
9 \text { sites }(\mathrm{U})\end{array}$ & Community & 1995-96 & $5-14$ & $\begin{array}{r}1346(\mathrm{R}) \\
407(\mathrm{U})\end{array}$ & $\begin{array}{l}\text { Systematic } \\
\text { random }\end{array}$ & Cyanomethaemoglobin & $\begin{array}{l}80.4(\mathrm{R}) \\
70.5(\mathrm{U})\end{array}$ \\
\hline $\begin{array}{l}\mathrm{HKI} / \mathrm{IPHN} \\
(1999)^{21}\end{array}$ & Rural & 10 sites & Community & 1997-98 & $\begin{array}{r}6-11 \\
11-16\end{array}$ & $\begin{array}{l}328 \\
196\end{array}$ & Random & HemoCue & $\begin{array}{l}38.4 \S \\
43.0\end{array}$ \\
\hline $\begin{array}{l}\text { Salamatullah } \\
\text { \& Yusuf } \\
(1997)^{26}\end{array}$ & Rural & 1 subdistrict & School & 1996 & $7-10$ & 400 & Selected & HemoCue & $51.5 \S$ \\
\hline $\begin{array}{l}\text { Ahmed et al. } \\
(1996)^{29}\end{array}$ & Urban & Dhaka city & School & 1990 & $5-12$ & 242 & Selected & Cyanomethaemoglobin & 20.0 \\
\hline $\begin{array}{l}\text { Ahmed et al. } \\
(1996)^{30}\end{array}$ & Urban & Dhaka city & School & 1992 & $12-15$ & 225 & Selected & Cyanomethaemoglobin & 22.0 \\
\hline $\begin{array}{l}\text { Ahmed } \\
\text { et al. }{ }^{32} \text { (2000) }\end{array}$ & Periurban & 5 subdistricts & School & 1996 & $11-16$ & 548 & Random & Cyanomethaemoglobin & 27.0 \\
\hline $\begin{array}{l}\text { Ahmed et al. } \\
(1997)^{34}\end{array}$ & Urban & Dhaka city & Factory & 1996 & $11-19$ & 388 & Random & Cyanomethaemoglobin & 44.0 \\
\hline
\end{tabular}

R, rural; U, urban.

*Defined by a haemoglobin level of $<120 \mathrm{gl}^{-1}$.

†Rural male.

$\ddagger$ Rural female.

$\S$ Haemoglobin level $<115 \mathrm{gl}^{-1}$. 
found to have anaemia although only $0.5 \%$ had severe anaemia $^{26}$. In 1996 Hyder et al. ${ }^{27}$ in a study of rural children aged 11-19 years showed that 69\% of 49 males and 61\% of 69 females were anaemic. In 1998 a study of 164 children in grades 3-5 from two rural schools in northwestern Bangladesh showed a prevalence of $31 \%$ for anaemia $^{28}$.

In urban populations we found that $20 \%$ of 242 school children aged 5-12 years (study period: 1990$)^{29}$, and $22 \%$ of 225 adolescent girls aged 12-15 years were anaemic (study period: 1993) ${ }^{30}$. In 1995 Sultana et al. ${ }^{31}$ found that $21 \%$ of 136 rural schoolgirls aged 11-17 years in Gazipur district had anaemia. In 1996, a study of 548 schoolgirls aged 11-16 years in the periurban area of Dhaka district showed a prevalence of $27 \%$ for anaemia, while none of them had severe anaemia ${ }^{32}$. Studies in adolescent female factory workers in Dhaka city have also shown a high prevalence of anaemia $(44-49 \%)^{33,34}$.

In conclusion, although the situation of anaemia among school-age and adolescent children has improved over the years, the current magnitude of the problem in both urban and rural areas is clearly a significant public health concern. The situation appears to be worse in females than males. Furthermore, in urban populations the problem is more serious among adolescent female factory workers.

\section{Adult males}

The survey of $1975 / 76$ revealed that the prevalence of anaemia in adult males in rural areas was $62 \%{ }^{18}$ (Table 5).
The rate was $60 \%$ in $1981 / 82^{19}$ and $68 \%$ in $1995 / 96^{20}$. In 1978, Saha and $\mathrm{Ahmad}^{22}$ reported that $58 \%$ of the males in rural areas with a safe water supply and $57 \%$ in areas with no safe water supply had anaemia. In 1996 Hyder et al. ${ }^{27}$, in a rural population of 57 males aged 20-48 years, showed a prevalence of $68 \%$ for anaemia.

To summarize, based upon the limited data for adult males in Bangladesh, there has not been much change in the prevalence of anaemia over the past few decades and the magnitude of the problem is a cause for concern.

\section{Adult females}

The survey of 1962/64 indicated a prevalence of 55\% for anaemia (haemoglobin level below $120 \mathrm{gl}^{-1}$ ) among rural non-pregnant and non-lactating (NPNL) women ${ }^{17}$, which increased to $70 \%$ in $1975 / 76^{18}, 74 \%$ in $1981 / 82^{19}$ and $81 \%$ in $1995 / 96^{20}$ (Table 5). The survey of 1995/96 also revealed that the prevalence of anaemia was higher in rural areas compared with urban areas ${ }^{20}$. During the $1997 / 98$ national vitamin A survey $45 \%$ of the non-pregnant women in rural areas were found to have anaemia ${ }^{21}$, although the rate of severe anaemia (haemoglobin level below $70 \mathrm{gl}^{-1}$ ) was less than $1.0 \%{ }^{21}$. In $1975 / 76$, a survey of haematocrit values from 2445 non-pregnant women in the Matlab subdistrict showed a prevalence of $60 \%$ for anaemia ${ }^{35}$. In 1978, Saha and Ahmad $^{22}$ showed that $70 \%$ of the NPNL women in rural areas with a safe water supply and $73 \%$ in areas with no safe water supply had anaemia. In 1996 Hyder et ll $^{27}$, in a rural population of 159 non-pregnant

Table 5 Summary of the prevalence data on anaemia among adult males and non-pregnant females in Bangladesh

\begin{tabular}{|c|c|c|c|c|c|c|c|c|c|}
\hline Reference & Area & Place & Setting & $\begin{array}{l}\text { Study } \\
\text { period }\end{array}$ & Sex & $\begin{array}{l}\text { Sample } \\
\text { size }\end{array}$ & $\begin{array}{l}\text { Sampling } \\
\text { design }\end{array}$ & Haemoglobin method & $\begin{array}{c}\text { Prevalence } \\
\text { of anaemia } \\
(\%)^{\star}\end{array}$ \\
\hline $\begin{array}{l}\text { US-DHEW } \\
(1966)^{17}\end{array}$ & $\begin{array}{l}\text { Urban } \\
\text { and rural }\end{array}$ & 54 sites & Community & $1962-64$ & $\begin{array}{l}\text { Male } \\
\text { Female }\end{array}$ & $\begin{array}{l}630(\mathrm{R}) \\
177(\mathrm{R})\end{array}$ & $\begin{array}{l}\text { Multistage } \\
\text { random }\end{array}$ & Cyanomethaemoglobin & $\begin{array}{l}69.0 \dagger \\
55.0\end{array}$ \\
\hline $\begin{array}{l}\text { INFS } \\
(1977)^{18}\end{array}$ & Rural & 12 sites & Community & $1975-76$ & $\begin{array}{l}\text { Male } \\
\text { Female }\end{array}$ & $\begin{array}{l}590 \\
437\end{array}$ & $\begin{array}{l}\text { Two-stage } \\
\text { systematic } \\
\text { random }\end{array}$ & Cyanomethaemoglobin & $\begin{array}{l}62.0 \\
70.0\end{array}$ \\
\hline $\begin{array}{l}\text { INFS } \\
(1983)^{19}\end{array}$ & Rural & 12 sites & Community & $1981-82$ & $\begin{array}{l}\text { Male } \\
\text { Female }\end{array}$ & $\begin{array}{l}628 \\
442\end{array}$ & $\begin{array}{l}\text { Two-stage } \\
\text { systematic } \\
\text { random }\end{array}$ & Cyanomethaemoglobin & $\begin{array}{l}60.0 \\
74.0\end{array}$ \\
\hline $\begin{array}{l}\text { Jahan \& } \\
\text { Hossain } \\
(1998)^{20}\end{array}$ & $\begin{array}{l}\text { Rural } \\
\text { and urban }\end{array}$ & $\begin{array}{r}32 \text { sites }(\mathrm{R}) \\
9 \text { sites }(\mathrm{U})\end{array}$ & Community & $1995-96$ & $\begin{array}{l}\text { Male } \\
\text { Female }\end{array}$ & $\begin{array}{l}1601(\mathrm{R}) \\
1322(\mathrm{R})\end{array}$ & $\begin{array}{l}\text { Systematic } \\
\text { random }\end{array}$ & Cyanomethaemoglobin & $\begin{array}{l}68.0 \\
81.0\end{array}$ \\
\hline $\begin{array}{l}\text { HKI/IPHN } \\
(1999)^{21}\end{array}$ & Rural & 10 sites & Community & $1997-98$ & Female & 1082 & Random & HemoCue & 45.0 \\
\hline $\begin{array}{l}\text { Saha \& } \\
\text { Ahmad } \\
(1991)^{22}\end{array}$ & Rural & 2 subdistricts & Community & 1978 & $\begin{array}{l}\text { Male‡ } \\
\text { Male§ } \\
\text { Female‡ } \\
\text { Female§ }\end{array}$ & $\begin{array}{r}164 \\
70 \\
144 \\
79\end{array}$ & Selected & Cyanomethaemoglobin & $\begin{array}{l}58.0 \ddagger \\
57.0 \S \\
70.0 \ddagger \\
73.0 \S\end{array}$ \\
\hline $\begin{array}{l}\text { Huffman } \\
\text { et al. } \\
(1985)^{35}\end{array}$ & Rural & $\begin{array}{l}\text { Comilla } \\
\text { district }\end{array}$ & Community & $1975-76$ & Female & 2445 & Selected & Haematocrit & 60.0 \\
\hline Huq $(1994)^{33}$ & Urban & Dhaka city & Factory & 1993 & Female & 63 & Selected & Cyanomethaemoglobin & 53.0 \\
\hline $\begin{array}{l}\text { Hyder et al. } \\
(1998)^{27}\end{array}$ & Rural & $\begin{array}{l}\text { Mymensingh } \\
\text { district }\end{array}$ & Community & 1996 & Female & 159 & Selected & Cyanomethaemoglobin & 73.0 \\
\hline
\end{tabular}

$\mathrm{R}$, rural; U, urban.

* Defined by a haemoglobin level of $<130 \mathrm{gl}^{-1}$ for males and $<120 \mathrm{gl}^{-1}$ for females.

† Haemoglobin level $<139 \mathrm{gl}^{-1}$.

$\ddagger$ In an area with a safe water supply.

$\S$ In an area with no safe water supply. 
Table 6 Summary of the prevalence data on anaemia among pregnant women in Bangladesh

\begin{tabular}{|c|c|c|c|c|c|c|c|c|c|}
\hline Reference & Area & Place & Setting & $\begin{array}{l}\text { Study } \\
\text { period }\end{array}$ & $\begin{array}{l}\text { Gestation } \\
\text { period }\end{array}$ & $\begin{array}{l}\text { Sample } \\
\text { size }\end{array}$ & $\begin{array}{l}\text { Sampling } \\
\text { design }\end{array}$ & Haemoglobin method & $\begin{array}{c}\text { Prevalence } \\
\text { of anaemia } \\
(\%)^{*}\end{array}$ \\
\hline $\begin{array}{l}\text { US-DHEW } \\
(1966)^{17}\end{array}$ & $\begin{array}{l}\text { Urban and } \\
\text { rural }\end{array}$ & 54 sites & Community & $1962-64$ & n.a. & $135(\mathrm{R})$ & $\begin{array}{l}\text { Multistage } \\
\text { random }\end{array}$ & Cyanomethaemoglobin & $59.5 \dagger$ \\
\hline $\begin{array}{l}\text { INFS } \\
(1977)^{18}\end{array}$ & Rural & 12 sites & Community & $1975-76$ & n.a. & 174 & $\begin{array}{l}\text { Two-stage } \\
\text { systematic } \\
\text { random }\end{array}$ & Cyanomethaemoglobin & 50.0 \\
\hline $\begin{array}{l}\text { INFS } \\
(1983)^{19}\end{array}$ & Rural & 12 sites & Community & $1981-82$ & n.a. & 279 & $\begin{array}{l}\text { Two-stage } \\
\text { systematic } \\
\text { random }\end{array}$ & Cyanomethaemoglobin & 47.0 \\
\hline $\begin{array}{l}\text { Jahan \& } \\
\text { Hossain } \\
(1998)^{20}\end{array}$ & $\begin{array}{l}\text { Rural and } \\
\text { urban }\end{array}$ & $\begin{array}{r}32 \text { sites }(R) \\
9 \text { sites }(U)\end{array}$ & Community & 1995-96 & n.a. & $\begin{array}{l}70(\mathrm{R}) \\
15(\mathrm{U})\end{array}$ & $\begin{array}{l}\text { Systematic } \\
\text { random }\end{array}$ & Cyanomethaemoglobin & $\begin{array}{l}60.0(\mathrm{R}) \\
53.0(\mathrm{U})\end{array}$ \\
\hline $\begin{array}{l}\mathrm{HKI} / \mathrm{IPHN} \\
(1991))^{21}\end{array}$ & Rural & 10 sites & Community & $1997-98$ & n.a. & 120 & Random & HemoCue & 49.2 \\
\hline $\begin{array}{l}\text { Saha \& } \\
\text { Ahmad } \\
(1991)^{22}\end{array}$ & Rural & 2 subdistricts & Community & 1978 & n.a. & $\begin{array}{l}95 \ddagger \\
41 \S\end{array}$ & Selected & Cyanomethaemoglobin & $\begin{array}{l}42.0 \ddagger \\
53.0 \S\end{array}$ \\
\hline $\begin{array}{l}\text { Hyder et al. } \\
(1998)^{37}\end{array}$ & Rural & $\begin{array}{l}\text { Mymensingh } \\
\text { district }\end{array}$ & Community & 1997 & n.a. & 90 & Selected & HemoCue & 54.0 \\
\hline $\begin{array}{l}\text { Osendrap } \\
\text { et al. } \\
(1998)^{36}\end{array}$ & Urban slum & Dhaka city & Community & n.a. & $12-16$ weeks & 559 & Selected & Cyanomethaemoglobin & 34.6 \\
\hline $\begin{array}{l}\text { Quazi et al. } \\
(1993)^{39}\end{array}$ & Urban & Dhaka city & $\begin{array}{l}\text { Maternity } \\
\text { clinic }\end{array}$ & 1990 & $\begin{array}{l}12-16 \text { weeks } \\
24-28 \text { weeks } \\
\text { At delivery }\end{array}$ & $\begin{array}{r}209 \\
89 \\
28\end{array}$ & Selected & Cyanomethaemoglobin & $\begin{array}{l}21.0 \\
32.6 \\
43.0\end{array}$ \\
\hline $\begin{array}{l}\text { Hasin et al. } \\
(1996)^{40}\end{array}$ & Urban & Dhaka city & $\begin{array}{l}\text { Maternity } \\
\text { clinic }\end{array}$ & 1993 & At delivery & 151 & Selected & Cyanomethaemoglobin & 20.0 \\
\hline $\begin{array}{l}\text { Sultana } \\
(1999)^{41}\end{array}$ & Urban & Dhaka city & $\begin{array}{l}\text { Maternity } \\
\text { clinic }\end{array}$ & 1998 & 20-32 weeks & 389 & Random & Cyanomethaemoglobin & 39.0 \\
\hline
\end{tabular}

$\mathrm{R}$, rural; U, urban, n.a., not available.

${ }^{\star}$ Defined by a haemoglobin level of $\left\langle 110 \mathrm{gl}^{-1}\right.$.

$\dagger$ Haemoglobin level $<120 \mathrm{gl}^{-1}$.

$\ddagger$ In an area with a safe water supply.

$\S$ In an area with no safe water supply.

women aged $20-48$ years, showed a prevalence of $73 \%$ for anaemia. In 1993 in a study of 63 females working in the garment factories of Dhaka city, $53 \%$ had anaemia ${ }^{33}$.

In summary, although the prevalence of anaemia among non-pregnant women has decreased over the past few decades it is still a significant public health problem.

\section{Pregnant and lactating women}

Table 6 summarizes the major findings on the prevalence of anaemia in pregnant women. The survey of 1975/76 showed a prevalence of $50 \%$ for anaemia (haemoglobin level below $110 \mathrm{gl}^{-1}$ ) among pregnant, lactating or pregnant and lactating women ${ }^{18}$ which dropped to $47 \%$ in $1981 / 82^{19}$. The survey of $1995 / 96$ revealed that the overall prevalence of anaemia in pregnant women was $59 \%$, being $60 \%$ in rural areas and $53 \%$ in urban areas ${ }^{20}$. Among lactating women, it was $83.7 \%$ in rural areas and $80.9 \%$ in urban areas ${ }^{20}$. During the $1997 / 98$ national vitamin A survey, the prevalence of anaemia among pregnant women was found to be $49 \%$ but none had severe anaemia ${ }^{21}$. In 1978 Saha and Ahmad ${ }^{22}$ showed that $42 \%$ of pregnant, lactating or pregnant and lactating women in rural areas with a safe water supply had anaemia, with $53 \%$ having anaemia in areas with no safe water supply, indicating that poor hygiene is related to the severity of the anaemia. A study of 559 women at 12-16 weeks of gestation from urban slums in Dhaka showed a prevalence of $34.6 \%$ for anaemia ${ }^{36}$. In 1997 a study in a rural population showed that $54 \%$ of the 90 pregnant women were anaemic and only $1 \%$ had severe anaemia ${ }^{37}$.

A retrospective study based on hospital records (June 1989-June 1990) of 1063 women at different stages of pregnancy of poor socioeconomic group in Dhaka city showed the prevalence of anaemia to be almost universal $(99.2 \%)^{38}$. Furthermore, $71.0 \%, 75.4 \%$ and $65.6 \%$ were found to be severely anaemic during the first, second and third trimesters, respectively ${ }^{38}$. In this study the high prevalence of anaemia may be explained by the fact that the haemoglobin levels were measured for those who were suspected to be anaemic. In 1990 a longitudinal study done by Quazi et $a l^{39}$ in a group of poor urban pregnant women, who attended a local maternity hospital in Dhaka city, showed the prevalence of anaemia to be $21.0 \%$ during $12-16$ weeks of gestation $(n=209), 32.6 \%$ during $24-28$ weeks $(n=89)$ and $43.0 \%$ at delivery $(n=$ 28). In 1993 in a clinic-based study of 151 pregnant women at delivery we found a prevalence of $20 \%$ for anaemia ${ }^{40}$, where $80 \%$ of the women had received routine supplementation of iron and folate tablets since their first antenatal visit. Recently, in a representative sample of 
389 pregnant women at 20-32 weeks of gestation of poor socioeconomic group in Dhaka city, on their first visit to a local maternity hospital, a prevalence of $39 \%$ was found for anaemia ${ }^{41}$. However, only $0.5 \%$ of these women had severe anaemia (haemoglobin level below $\left.70 \mathrm{gl}^{-1}\right)^{41}$.

To conclude, data from the available studies including the national nutrition surveys clearly indicate a high prevalence of anaemia in pregnant women ranging from $20 \%$ to $59 \%$, excluding the retrospective data, which were from a seemingly biased study. These rates fall within the criteria required by the WHO classification as necessary for the definition of a moderate to severe public health problem $^{2}$.

\section{Summary of the situation analysis}

The overall analysis and assessment of the situation in relation to anaemia among different population groups leads to the conclusion that although there is a decreasing trend of anaemia in preschool and school-age children and adolescents over the past three decades, the magnitude of the problem still remains a significant public health concern. In adult males, the prevalence has not changed over the years, even though the limited information makes it difficult to assess the true situation. The prevalence of anaemia among non-pregnant women has decreased over the years, but the magnitude of the problem is still a considerable issue. Similarly the prevalence of anaemia in pregnant and lactating women is at a level which is high enough to cause considerable concern. To summarize, while overall levels of anaemia in Bangladesh are still very high, prevalence figures on severe anaemia are almost non-existent. Nevertheless, from the scanty data that exist, it appears that severe anaemia among different population groups is less frequent in Bangladesh, possibly present among only $2-3 \%$ of the population.

\section{Aetiology of anaemia}

In Bangladesh, data on the aetiology of anaemia are limited and mainly derived from dietary information. The four successive national nutrition surveys (1962/64, 1975/ 76, 1981/82 and 1995/96) in Bangladesh were all conducted with a special emphasis on dietary nutrient intakes. It was found that average daily iron intake by the rural population increased from $9.4 \mathrm{mg}$ in $1962 / 64{ }^{17}$ to $22.2 \mathrm{mg}$ in $1975 / 76^{18}$ and $23.4 \mathrm{mg}$ in $1981 / 82^{19}$; while in the survey of $1995 / 96$ the mean daily iron intake was found to be $11.0 \mathrm{mg}^{20}$. The surveys in 1975/76 and 1981/82 revealed that the average iron intake was almost three times higher than the recommended daily allowance (RDA), based upon the criteria of $\mathrm{WHO}^{18,19}$. This contrasted with the recent survey in 1995/96, where the average iron intake was about $50 \%$ of the Indian-derived RDA, a substantial drop from that reported in the earlier studies ${ }^{20}$. In part this difference might be accounted for by changes in the current recommendations of iron intake for diets with low bioavailability. Additionally, there have been changes in the reference food composition tables which have been revised and updated after reanalysis of foods for iron content using modern techniques ${ }^{42}$. In consequence, the iron contents of several foods in the new edition differ from earlier editions. For example, rice is a major source of iron in the diets of the Bangladeshi population, but the value for iron in rice in the current table is about one-third of that in the earlier edition. When the dietary iron intakes found in the 1975/76 and 1981/82 surveys were recalculated using the values from the new edition of the food composition table, the mean iron intakes dropped to 12.2 and $11.1 \mathrm{mg} \mathrm{day}^{-1}$ in the surveys of $1975 / 76$ and 1981/ 82 , respectively. In this analysis only cereal intakes were considered because it contributed almost $80 \%$ of the total iron intake in the population surveyed. Thus, it is clear that the dietary intake of iron is much lower than the RDA and has not changed since the 1975/76 survey.

Besides national nutrition surveys, a number of studies have investigated the dietary intake of iron in urban populations. A study of 385 adolescent schoolgirls aged 10-16 years in Dhaka city revealed that the mean iron intake was only $10 \mathrm{mgday}^{-1}$, and $77 \%$ of the girls had intakes of iron which were below the RDA, using Indian standards ${ }^{43}$. For 82 females, aged $17-24$ years and living in a college hostel in Dhaka city, the mean iron intake was found to be $62 \%$ of the $\mathrm{RDA}^{44}$. Sarker et al. ${ }^{45}$ investigated the dietary nutrient intake of females working in garment factories in Dhaka city and showed that the mean intake of iron by girls aged 10-12 years was higher than the RDA and for females aged 13-45 years it ranged from $84 \%$ to $88 \%$ of the RDA. Huq ${ }^{33}$ also showed that mean iron intake of female garment factory workers was $67 \%$ of the RDA. Further, nearly $86 \%$ of the adolescent and $92 \%$ of the adult female workers did not meet the RDA ${ }^{33}$. Sultana et al. ${ }^{46}$ also reported poor intakes of iron (51-78\% of the RDA) by pregnant women of poor socioeconomic group attending a local maternity hospital in Dhaka city. Husain ${ }^{47}$ reported that the mean iron intake of 50 non-resident female students, aged 18-30 years, of Dhaka University was 57\% of the RDA. In a study of 252 rickshaw pullers, the largest group of manual workers in Dhaka city, nearly $84 \%$ had iron intakes of less than the RDA ${ }^{48}$.

In general the data on dietary intake of iron leads to the conclusion that the overall intake of dietary iron is inadequate. Furthermore, all national surveys conducted in Bangladesh revealed that over $95 \%$ of the dietary iron was contributed by plant sources, indicating the possibility of poor bioavailability owing to the presence of a large number of absorption inhibitors. The situation is compounded by the low intake of enhancers, such as vitamin $\mathrm{C}$, and storage mobilizers, such as vitamin A. Thus, dietary factors may precipitate a high prevalence of anaemia in Bangladesh.

The data on iron status among the Bangladeshi population are scarce. In a study on urban schoolgirls we found 
that $15 \%$ had subnormal serum iron levels $(<$ $7.16 \mu \mathrm{moll}^{-1}$ ) and $25 \%$ were iron deficient judged by serum transferrin saturation $(<15 \%)^{30}$. In that study we also observed a negative correlation between serum total iron-binding capacity and haemoglobin level, suggesting that a significant proportion of anaemia might be related to iron deficiency ${ }^{30}$. Among adolescent schoolgirls in the periurban area of Dhaka district we found that $21 \%$ had iron deficient erythropoiesis (serum transferrin saturation $<16 \%$ ) and $17 \%$ were iron deficient judged by their serum ferritin level $\left(<12 \mu \mathrm{gl}^{-1}\right)^{32}$. Further, it was observed that $32 \%$ of all anaemic girls had iron deficiency anaemia (haemoglobin $<120 \mathrm{gl}^{-1}$ and serum ferritin $<12 \mu \mathrm{gl}^{-1}$ ) and a large proportion of the girls had a risk of iron deficiency (serum ferritin $<20 \mu \mathrm{g} \mathrm{l}^{-1}$ ) 32 . In a study of 164 school-age children in a rural area showed a prevalence of $30 \%$ for iron deficiency judged by the serum ferritin level and $14 \%$ were suffering from iron deficiency anaemia ${ }^{28}$. Among adolescent females working in the garment factories in Dhaka city we found that nearly $40 \%$ were iron deficient judged by serum transferrin saturation ${ }^{34}$. Most recently, in a supplementation trial among adolescent female factory workers, we found that $80 \%$ of 289 subjects with a haemoglobin level below $121 \mathrm{gl}^{-1}$ at baseline had iron deficiency judged by serum ferritin level $^{49}$. In a study among non-pregnant women living in urban slums in northwestern Bangladesh, Kolsteren et $a l .^{50}$ showed that $53 \%$ of 171 subjects who completed a supplementation trial had low serum transferrin saturation levels $(<16 \%)$ and $23 \%$ had iron deficiency using a cut-off point of $12 \mu \mathrm{gl}^{-1}$ for serum ferritin. Based on limited data on the measurement of iron status in addition to dietary factors, it may be concluded that a large proportion of the anaemia is related to iron deficiency.

Intestinal helminths such as Ascaris lumbricoides (ascaris) and Ancyclostoma duodenale (hookworm) are prevalent in Bangladesh in all age groups ${ }^{51-53}$. However, data on the aetiology of anaemia in relation to parasitic infection are limited. Recently, Husain ${ }^{53}$ showed that the risk of anaemia was almost doubled (odds ratio $=1.87$ ) in cases of hookworm infestation. There was also a higher risk of anaemia by infection with Giardia (odds ratio= 1.12), but no relationship was reported between anaemia and infestation with Ascaris lumbricoides and Trichuris trichiura $^{53}$.

\section{Discussion}

This paper reviews the present situation of anaemia in Bangladesh and thus summarizes available information to provide the magnitude and trends in anaemia in the country. It also focuses on the aetiology of anaemia. The available data on the prevalence of anaemia in different population groups have clearly demonstrated that the magnitude of the problem is considerable, especially among preschool children, adolescent girls, women of reproductive age and pregnant women. Although the rates of severe anaemia are very low, the overall magnitude of the problem of anaemia remains a major public health issue and the level is high enough to cause significant concern. Based on information on the aetiology of anaemia, it is very likely that iron deficiency is the major cause of anaemia in the Bangladeshi population. Other dietary factors, in addition to parasitic infestations, may also precipitate the high prevalence of anaemia in Bangladesh. However, more focused studies are needed to identify the causes of anaemia, such as the prevalence of haemoglobinopathies.

In 1990, the World Summit for Children adopted a global objective which called for the reduction of iron deficiency anaemia in women by one-third of 1990 levels by the year 2000. The goals were reaffirmed in 1991 at the Ending Hidden Hunger Conference and in 1992 at the International Conference of Nutrition. Despite the political commitment and a quantum increase in terms of the awareness of the problem, there has not yet been much progress in the Bangladeshi national programme for the prevention and control of anaemia. There are several strategies available, which if effectively implemented can achieve a dramatic level of success in the prevention and control of nutritional anaemia with modest investment. These include dietary improvements, fortification of foods with iron, providing iron through medicinal supplementation, and through public health approaches such as controlling infestations. All these strategies improve iron status in some contexts, although it is important to appreciate that no single intervention strategy is likely to be entirely successful under all circumstances. Ideally, the acceleration of sustainable progress towards the substantial reduction of iron deficiency anaemia will require a comprehensive programme that includes an appropriate mix of interventions. In Bangladesh, the focus of the major thrust so far has been to provide supplements to pregnant women. However, the impact of this measure has been uneven owing to the problems of appropriate policies and inadequate implementation of the programme.

Given the fact that there is high prevalence of anaemia, and the dietary intake of iron is unlikely to show any significant improvement in the near future, iron supplementation should be strengthened as a short-term strategy for the prevention and control of iron deficiency anaemia. In Bangladesh, as in most other developing countries, pregnant and lactating women should be considered as the highest priority target group for an iron-supplementation programme. This should provide fundamental benefit to mothers and babies, and can prevent long lasting, undesirable effects. Thus for immediate action, there is a need to strengthen the iron folate tablet-supplementation programme during pregnancy. It has recently been emphasized that iron supplementation before pregnancy may be more beneficial in terms of improved iron stores and impact on health ${ }^{54}$. Thus, adolescent girls and women 
of reproductive age should also be considered as a priority target group and every effort should be made to develop an iron-supplementation programme as a preventive measure for these groups. However, the distribution of iron supplements can be phased out as soon as long term and more sustainable approaches take effect.

Though at the present time specific target goal setting for a food-based strategy is not feasible, attempts should be made for the vulnerable groups to improve their dietary iron intake by encouraging the consumption of iron-rich foods and advocating appropriate changes in food habits to increase dietary iron absorption. In Bangladesh, food fortification holds a considerable potential to reduce and control iron deficiency anaemia. Given the magnitude of the problem of anaemia, at this point in time, a pilot project for targeted iron fortification of suitable food items to those who are most vulnerable needs to be initiated. Further, a programme of deworming needs to be taken up at the community level and it should be linked with not only the anaemia prophylaxis programme but also with all the development programmes in the country.

In conclusion, the magnitude of the problem makes it clear that there is a need for a more comprehensive strategy that should be aimed at sustainable long-term approaches in combination with short-term measures for immediate impact on the prevention and control of anaemia. To achieve the goal of a substantial reduction in the prevalence of anaemia, a multidisciplinary approach is essential, with active collaboration of all sectors involved, including government, donor agencies, local academic institutions, non-governmental organizations and local communities.

\section{References}

$1 \mathrm{WHO} / \mathrm{UNICEF} / \mathrm{UNU}$. Indicators and Strategies for Iron Deficiency and Anaemia Programmes. Report of Consultation, Geneva, 6-10 December 1993. Geneva: WHO, 1997.

2 FAO/WHO. Theme paper no. 6. In: International Conference on Nutrition: Major Issues for Nutrition Strategies. Geneva: WHO, 1992; 12.

3 Hallberg L. Iron. In: JS Garrow, WPT James, eds. Human Nutrition and Dietetics. London: Churchill Livingstone, 1993; 174-207.

4 FAO/WHO Expert Consultation. Requirements of Vitamin A, Iron, Folate and Vitamin B 12. Rome: FAO, 1990.

5 Stoltzfus RJ, Chwaya HM, Tielsch JM, Schulze KJ, Albonico $\mathrm{M}$, Savioli L. Epidemiology of iron deficiency anaemia in Zanzibari schoolchildren: the importance of hookworms. Am.J. Clin. Nutr. 1997; 65: 153-9.

6 Hershko C, Peto TEA, Weatheral DJ. Regular review. Iron and infection. BMJ 1988; 296: 660-4.

7 Mejia LA. Role of vitamin A in iron deficiency anemia. In: Fomon SJ, Zlotkin S, eds. Nutritional Anemias. Nestle Nutrition Workshop Series, Vol. 30. Vevey, Switzerland: Nestle Ltd/New York: Raven Press, 1992, 93-101.

8 INACG. Action strategy for combating iron deficiency anaemia, a summary of the XII INACG Meeting. Washington, DC: International Nutritional Anaemia Consultative Group, 1990.
9 Viteri FE. The consequences of iron deficiency and anaemia in pregnancy on maternal health, the foetus and the infants. SCN News 1994; 11: 14-18.

10 WHO. In Control of Nutritional Anaemia with Special Reference to Iron Deficiency. Technical Report Series No. 580. Geneva: WHO, 1975; 6.

11 MOHFW. Bangladesh Country Paper on Nutrition. Dhaka: Ministry of Health and Family Welfare, Government of Bangladesh, 1995.

12 Barker DJP. Mothers, Babies and Disease in Later Life London: BMJ Publishing House, 1994.

13 Edgerton VR, Gardner GW, Ohira Y, Gunawardena KA, Senewiratne B. Iron deficiency anaemia and its effect on work productivity and activity patterns. BMJ 1979; 2: 1546 9.

14 Pollitt E, Saco-Pollitt C, Leibell RL, Viteri FE. Iron deficiency and behavioral development in infants and preschool children. Am.J. Clin. Nutr. 1986; 43: 555-65.

15 Ross J, Horton S. Economic Consequences of Iron Deficiency. Ottawa, Canada: Micronutrient Initiative, 1998.

16 DeMaeyer EM, Adiels-Tegman M. The prevalence of anaemia in the world. World Health Stat. Q. 1985; 38(3): 302-16.

17 US-DEHW. Nutrition Survey of East Pakistan, March 1962January 1964. Dhaka: United States Department of Education, Health and Welfare, Public Health Service, 1966.

18 INFS. Nutrition Survey of Rural Bangladesh, 1975-76. Dhaka, Bangladesh: Institute of Nutrition and Food Science, University of Dhaka, 1977.

19 INFS. Nutrition Survey of Rural Bangladesh, 1981-82. Dhaka, Bangladesh: Institute of Nutrition and Food Science, University of Dhaka, 1983.

20 Jahan K, Hossain M. Nature and Extent of Malnutrition in Bangladesh. Bangladesh National Nutrition Survey, 199596. Dhaka, Bangladesh: Institute of Nutrition and Food Science, University of Dhaka, 1998.

21 HKI/IPHN. Iron Deficiency Anaemia Throughout the Lifecycle in Rural Bangladesh. National Vitamin A Survey, 1997-98. Dhaka, Bangladesh: Helen Keller International/ Institute of Public Health Nutrition, 1999.

22 Saha A, Ahmad K. Anaemia in two rural Bangladesh communities, with and without the supply of safe drinking water. Bangladesh J. Nutr. 1991; 4(1): 1-8.

23 Rahman M, Islam S. Iron deficiency anaemia of children. In: Seventh Bangladesh Nutrition Conference, Dhaka. Dhaka: Nutrition Society of Bangladesh, 1997; 14 (abstract).

24 Sultana W. Nutritional status and dietary pattern of under-5 children of Dhaka University employees belonging to low socio-economic status. MSc. thesis, University of Dhaka, Dhaka, Bangladesh, 1995.

25 Nahar L, Barua S, Firoz G, Hossain A. Nutritional anaemia amongst underprivileged urban children - a study in a mother and child health centre in Dhaka city. Bangladesh J. Nutr. 1995; 8: 21-7.

26 Salamatullah Q, Yusuf HKM. Report of the iodine deficiency disorders indicator study in Savar, Bangladesh. Dhaka, Bangladesh: University of Dhaka, 1997.

27 Hyder SMZ, Chowdhury SA, Chowdhury AMR. Anaemia among apparently healthy males and females. In: Prevalence of Anaemia and Intestinal Parasites in a Rural Community of Bangladesh. Research Monograph Series No. 12. Dhaka, Bangladesh: Bangladesh Rural Advancement Committee, 1998; 1-11.

28 Veveka P, Ahmed F, Gebre-Medhin M, Greiner T. Relationships between vitamin A, iron status, and helminthiasis in Bangladeshi school children. Public Health Nutr. 2000 3(1): $83-9$.

29 Ahmed F, Khan MR, Mohiduzzaman M, Shaheen N, Barua S, Bhuyan MAH. Relationship between growth and nutrient status in school children of urban Bangladesh. In: Said HM, 
Rahman MA, Abdulla M, Vohora SB, Athar M, eds. Elements and Liver: Proceedings of the International Symposium on Trace Elements and Liver Diseases. Karachi, Pakistan: Hamdard Foundation, 1996; 26-33.

30 Ahmed F, Khan MR, Karim R, et al. Serum retinol and biochemical measures of iron status in adolescent schoolgirls in urban Bangladesh. Eur. J. Clin. Nutr. 1996; 50: 34651.

31 Sultana N, Khan MR, Ahmed F. Nutritional status and dietary pattern of adolescent school girls in a rural area. In: Seventh Bangladesh Nutrition Conference, Dhaka. Dhaka: Nutrition Society of Bangladesh, 1997; 58 (abstract).

32 Ahmed F, Khan MR, Islam M, Kabir I, Fuch G. Anaemia and iron deficiency among adolescent schoolgirls in peri-urban Bangladesh. Eur. J. Clin. Nutr. 2000; 54.

33 Huq SF. Nutritional profile and prevalence of anaemia in female garment workers. MSc. thesis, University of Dhaka, Dhaka, Bangladesh, 1994.

34 Ahmed F, Hasan N, Kabir Y. Vitamin A deficiency among adolescent female garment factory workers in Bangladesh. Eur. J. Clin. Nutr. 1997; 51: 698-702.

35 Huffman SL, Wolff M, Lowell S. Nutrition and fertility in Bangladesh: nutritional status of nonpregnant women. Am. J. Clin. Nutr. 1985; 42: 725-38.

36 Osendarp S, Wahid MA, Baqui AH, et al. Determinants of haemoglobin level during pregnancy and relationship with pregnancy outcome in Bangladeshi urban poor. In: Khan MSI, Rahim MA, eds. Seventh Annual Scientific Conference, Bangladesh: International Center for Diarrhoeal Disease Research, 1998; 72 (abstract).

37 Hyder SMZ, Chowdhury SA, Chowdhury AMR. Anaemia in pregnancy. In: Prevalence of Anaemia and Intestinal Parasites in a Rural Community of Bangladesh. Research Monograph Series No. 12. Dhaka, Bangladesh: Bangladesh Rural Advancement Committee, 1998; 12-20.

38 Ahmed FU, Das AM, Mostafa MG, Begum S, Haque YA. The Distribution of Birth Weight in an Urban Maternity Centre of Bangladesh. Dhaka: UNICEF, 1992.

39 Quazi S, Nahar B, Rahman MM, Sayeed S. Blood haemoglobin, total protein and albumin levels at different stages of gestation. Bangladesh J. Nutr. 1993; 6: 23-9.

40 Hasin A, Begum R, Khan MR, Ahmed F. Relationship between birth weight and biochemical measures of maternal nutritional status at delivery in Bangladeshi urban poors. Int. J. Food Sci. Nutr. 1996; 47: 273-9.

41 Sultana A. Prevalence of anaemia in pregnancy in poor urban women. MSc. thesis, University of Dhaka, Dhaka, 1999.
42 Gopalan C, Ramasastri BV, Balasubramanian SC, Rao BSN, Deosthale YG, Pant KC. Nutritive Value of Indian Foods. Hyderabad, India: Indian Council of Medical Research, 1993.

43 Ahmed F, Zareen M, Khan MR, Banu CP, Haq N, Jackson AA. Dietary pattern, nutrient intake and growth of adolescent school girls in urban Bangladesh. Public Health Nutr. 1998; 1(2): 83-92.

44 Akhter S, Pramanik MMA, Ali SMK. Nutritional status of girls (aged 17-24 years) residents of a college hostel. In: Seventh Bangladesh Nutrition Conference, Dhaka. Dhaka: Nutrition Society of Bangladesh, 1997; 42 (abstract).

45 Sarker BR, Abdullah M, Sarker SK. Dietary intake pattern among Bangladesh female workers in garment factories and their health problem. Bangladesh J. Nutr. 1993; 6: 73-8.

46 Sultana S, Nahar B, Quazi S. Dietary intake of micronutrients in normal state and during pregnancy. Bangladesh J. Nutr. 1990; 4: 19-25.

47 Husain N. Nutritional status of non-resident students of Dhaka University with special emphasis on trace elements. MSc. thesis, University of Dhaka, Dhaka, Bangladesh, 1996.

48 Ahmed F, Khandaker MAI. Dietary pattern and nutritional status of Bangladeshi manual workers (rickshaw pullers). Int. J. Food Sci. Nutr. 1997; 48: 285-91.

49 Ahmed F, Khan MR, Jackson AA. Weekly supplementation with iron/folate and vitamin A interact to improve anemia, iron status and vitamin A status in anemic teenage women in urban Bangladesh. Am. J. Clin. Nutr. 2000 (in press).

50 Kolsteren P, Rahman SR, Hilderbrand K, Diniz A. Treatment for iron deficiency anaemia with a combined supplementation of iron, vitamin A and zinc in women of Dinajpur, Bangladesh. Eur. J. Clin. Nutr. 1999; 53: 102-6.

51 Martin J, Keymer A, Isherwood R, Wainwright S. The prevalence and intensity of Ascaris lumbricoides infections in moslem children from northern Bangladesh. Trans. $R$. Soc. Trop. Med. Hyg. 1983; 77: 702-6.

52 Hall A, Anwar KS, Tomkins AM. Intensity of reinfection with Ascaris lumbricoides and its implications for parasite control. Lancet 1992; 330: 1253-7.

53 Hussain MM. Aetiology of Anaemia in Bangladesh. MPhil. thesis, Institute of Nutrition and Food Science, University of Dhaka, Dhaka, Bangladesh, 1996.

54 ACC/SCN. Controlling Iron Deficiency. Administrative Committee on Coordination/Subcommittee on Nutrition State-of-the-Art Series Nutrition Policy Discussion Paper No. 9. Geneva: United Nations, 1991. 